Martin C. J. Kneyber

Roel P. Gazendam

Dick G. Markhorst

Frans B. Plötz

\section{Length of storage of red blood cells does not affect outcome in critically ill children}

Accepted: 15 July 2008

Published online: 1 August 2008

(C) The Author(s) 2008

Sir: Length of red blood cell (RBC) storage has been proposed a contributing factor to adverse outcome after RBC transfusion. This may be explained by an impaired ability to transport or deliver oxygen, or the presence of leukocytes in stored RBC preparations producing potential deleterious pro-inflammatory mediators or bioactive lipids [1]. We hypothesized that length of RBC storage might explain our previously observed independent association between RBC transfusion and increased mortality, duration of mechanical ventilation (MV) and length of paediatric intensive care unit (PICU) stay in critically ill children [2].

For each time a patient was transfused in our previous study, length of $\mathrm{RBC}$ storage was retrieved from our hospital's blood bank [2]. Since we observed a dose-outcome relation between the number of RBC transfusions and mortality, we separately looked at single transfusion and multiple transfusions. The effect of RBC transfusion on oxygenation was assessed by the oxygenation index (OI, mean airway pressure times $\mathrm{FiO}_{2}$ divided by $\mathrm{PaO}_{2}$ ) and $\mathrm{PaO}_{2} / \mathrm{FiO}_{2}$ ratio. RBC preparations were leukocyte-depleted, but not irradiated. Statistical analysis was performed using the Student $t$-test; linear regression analysis was applied to study correlations. $P<0.05$ was accepted as statistically significant.

Data of 295 patients were studied, of whom $67(22.7 \%)$ were transfused; $39(58.2 \%)$ were transfused only once, the remaining 28 received multiple transfusions at different time intervals (range 2-14) (Table 1). Seventeen $(5.8 \%)$ patients died. The mean length of RBC storage was $16.7 \pm 0.6$ days $[25-75 \%$ interquartile range (IQR) 9-23 days]. Length of RBC storage was comparable between survivors and non-survivors. This remained after comparing single versus multiple transfusions. Differences in OI and $\mathrm{PaO}_{2} / \mathrm{FiO}_{2}$ ratio between the first day and fifth day after transfusion, duration of $\mathrm{MV}$ and length of PICU stay were not correlated with length of RBC storage.

Our findings indicate that our previous reported observed independent association between transfusion of leucocyte-depleted RBC preparations and increased morbidity in critically ill children could not be explained by length of RBC storage. Mortality was also not influenced by length of RBC storage, although our study might not be powered to detect this. To our knowledge, although the issue of RBC transfusion has been extensively studied in critically ill adults, no other paediatric data on length of RBC storage and outcome in critically ill children have been reported. Results from retrospective and prospective

Table 1 Effect of length of red blood cell storage on oxygenation and patient outcome

\begin{tabular}{|c|c|c|c|c|}
\hline & & Single transfusion $(N=39)$ & \multicolumn{2}{|c|}{ Multiple transfusions $(N=28)$} \\
\hline Mean length of RBC storage (days \pm SEM) & & $\begin{array}{l}14.6 \pm 1.3 \\
(25-75 \% \text { IQR } 7-20 \text { days })\end{array}$ & $\begin{array}{l}15.9 \\
(25-\end{array}$ & ys) \\
\hline \multicolumn{5}{|l|}{ Effect of length of RBC storage on oxygenation } \\
\hline & $R^{2}$ & $P$ value & $R^{2}$ & $P$ value \\
\hline $\begin{array}{l}\Delta \mathrm{OI} \text { day } 1 \text { to day } 5 \\
\Delta \mathrm{PaO}_{2} / \mathrm{FiO}_{2} \text { day } 1 \text { to day } 5\end{array}$ & $\begin{array}{l}0.036 \\
0.340\end{array}$ & $\begin{array}{l}0.684 \\
0.169\end{array}$ & $\begin{array}{r}<0.001 \\
0.025\end{array}$ & $\begin{array}{l}0.995 \\
0.517\end{array}$ \\
\hline \multicolumn{5}{|c|}{ Effect of length of RBC storage on patient outcome } \\
\hline $\begin{array}{l}\text { Duration of ventilation } \\
\text { Length of PICU stay }\end{array}$ & $\begin{array}{l}0.002 \\
0.001\end{array}$ & $\begin{array}{l}0.830 \\
0.827\end{array}$ & $\begin{array}{l}0.177 \\
0.047\end{array}$ & $\begin{array}{l}0.065 \\
0.268\end{array}$ \\
\hline
\end{tabular}

Effect of length of RBC storage on mortality

\begin{tabular}{lllll}
\hline & Survivors $(N=35)$ & Non-survivors $(N=4)$ & Survivors $(N=21)$ & Non-survivors $(N=7)$ \\
\hline Mean length of RBC storage (days \pm SEM) & $14.7 \pm 1.4$ & $13.5 \pm 3.0$ & $15.8 \pm 1.5$ & $16.0 \pm 3.5$
\end{tabular}

$\triangle O I$ difference in oxygenation index, $\triangle \mathrm{PaO}_{2} / \mathrm{FiO}_{2}$ difference in $\mathrm{PaO}_{2} / \mathrm{FiO}_{2}$ ratio, $\mathrm{RBC}$ red blood cell, $\mathrm{SEM}$ standard error of the mean 
observational studies on the association between RBC storage and outcome in critically ill adults are difficult to interpret as they yield conflicting results $[1,3]$. The outcome of (some of) these studies are probably confounded by a lack of transfusion policy and the use of leukocyte-non-depleted RBC preparations. Our observations on lack of correlation between change in oxygenation, duration of MV or PICU stay and length of RBC storage are compatible with experimental and clinical data indicating no difference in regional or global indexes of tissue oxygenation, or patient outcome in critically ill adults with organ failure [4-6].

Despite the limitations of our study (relatively small number of patients, single-center retrospective study and lack of transfusion algorithm), we conclude that no association between length of RBC storage and patient outcome could be demonstrated in our patient population. A prospective randomized trial comparing "fresh" versus "old" blood in critically ill (paediatric) patients seems warranted.

Open Access This article is distributed under the terms of the Creative Commons Attribution Noncommercial License which permits any noncommercial use, distribution, and reproduction in any medium, provided the original author(s) and source are credited.

\section{References}

1. Tinmouth A, Fergusson D, Yee IC, Hebert PC (2006) Clinical consequences of red cell storage in the critically ill. Transfusion 46:2014-2027

2. Kneyber MC, Hersi MI, Twisk JW, Markhorst DG, Plotz FB (2007) Red blood cell transfusion in critically ill children is independently associated with increased mortality. Intensive Care Med 33:1414-1422

3. Taylor RW, O'Brien J, Trottier SJ, Manganaro L, Cytron M, Lesko MF, Arnzen K, Cappadoro C, Fu M, Plisco MS, Sadaka FG, Veremakis C (2006) Red blood cell transfusions and nosocomial infections in critically ill patients. Crit Care Med 34:2302-2308
4. Raat NJ, Verhoeven AJ, Mik EG, Gouwerok CW, Verhaar R, Goedhart PT, de KD, Ince C (2005) The effect of storage time of human red cells on intestinal microcirculatory oxygenation in a rat isovolemic exchange model. Crit Care Med 33:39-45

5. Hebert PC, Chin-Yee I, Fergusson D, Blajchman M, Martineau R, Clinch J, Olberg B (2005) A pilot trial evaluating the clinical effects of prolonged storage of red cells. Anesth Analg 100:14331438

6. Walsh TS, McArdle F, McLellan SA, Maciver C, Maginnis M, Prescott RJ, McClelland DB (2004) Does the storage time of transfused red blood cells influence regional or global indexes of tissue oxygenation in anemic critically ill patients? Crit Care Med 32:364-371

M. C. J. Kneyber $(\varangle) \cdot$ R. P. Gazendam D. G. Markhorst - F. B. Plötz

Department of Paediatric Intensive Care, VU University Medical Center, Office 8 D 12, P.O. Box 7057, 1007 MB Amsterdam, The Netherlands e-mail: m.kneyber@vumc.nl

Tel.: +31-20-4442413

Fax: +31-20-4443045 